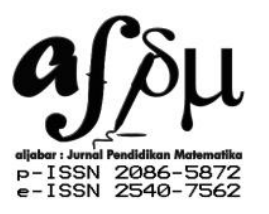

Al-Jabar: Jurnal Pendidikan Matematika

Vol. 8, No. 1, 2017, Hal 53 - 62

\title{
Analisis Kemampuan Komunikasi Dan Pemahaman Konsep Aljabar Linier Pada Mahasiswa Universitas Putra Indonesia 'YPTK' Padang
}

\author{
Syelfia Dewimarni \\ UPI YPTK Padang: Syelfia.dewimarni@gmail.com
}

\begin{abstract}
This study aims to describe the communication skills and understanding of students' concepts in linear algebra courses on the subject of vector. Students' ability and understanding concept of communication was described in a whole, students with high level and student with low level. This research in a descriptive it was done in academic year 20016/2017. The subject of this research was SI 10 class of UPI YPTK Padang who attended linier algebra class consisted 48 students. Research instrumentation was ability and understanding communication concept test. Test result was descripted quantitatively and some of students' answer was descripted qualitatively. Based on result, for the students' communication ability 63,58\% in a whole, 50,05\% in high level and 50\% in a low level had ability in a making a presentation with visual or picture to clearer the problem and to facilitate its solution. For students' understanding in communication concept $65,44 \%$ in a whole, $81,34 \%$ in high level and 46,29\% in low level who understanding concept ability in explain the concept and use the concept in right way.
\end{abstract}

Keyword: Communication; Concept Understanding; Linear Algebra.

\begin{abstract}
Abstrak
Penelitian ini bertujuan untuk mendeskripsikan kemampuan komunikasi dan pemahaman konsep mahasiswa dalam mata kuliah aljabar linier pada pokok bahasan vector. Kemampuan komunikasi dan pemahaman konsep mahasiswa dilihat secara keseluruhan, mahasiswa berkemampuan tinggi dan mahasiswa berkemampuan rendah. Bentuk penelitian ini adalah penelitian deskriptif. Subjek penelitian adalah mahasiswa semester 3 tahun ajaran 2016/2017 kelas SI 10 UPI YPTK Padang yang mengikuti mata kuliah aljabar linier dengan jumlah mahasiswa sebanyak 48 orang. Teknik pengumpulan data dalam penelitian ini adalah teknis tes yaitu soal-soal kemampuan komunikasi dan pemahaman konsep. Pengolahan data dilakukan dengan teknik triangulasi (mereduksi data, menyajikan data dan menarik kesimpulan). Berdasarkan hasil penelitian bahwa Untuk kemampuan komunikasi 63,58\% mahasiswa secara keseluruhan, 50,05\% mahasiswa yang berkemampuan tinggi, dan 50\% mahasiswa berkemampuan rendah mampu membuat sajian visual atau gambar untuk memperjelas permasalahan dan memfasilitasi penyelesaiannya. Untuk pemahaman konsep mahasiswa secara keseluruhan 65,44\%, mahasiswa yang berkemampuan tinggi 81,34\%, mahasiswa berkemampuan rendah 46,29\% mempunyai pemahaman konsep mampu menjelaskan konsep dengan benar dan menggunakan konsep dengan benar.
\end{abstract}

Kata Kunci: Komunikasi; Pemahaman Konsep; Aljabar Linear. 


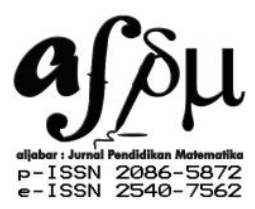

Al-Jabar: Jurnal Pendidikan Matematika

Vol. 8, No. 1, 2017, Hal 53 - 62

\section{PENDAHULUAN}

Matematika merupakan salah satu ilmu pendidikan yang mempunyai peranan penting dalam kehidupan sehari-hari matematika sebagai bahasa simbol mengandung makna bahwa matematika bersifat universal dan dapat dipahami oleh setiap orang kapan dan di mana saja (Arifin, Trapsilasiwi, \& Fathillah, 2016), sehingga matematika menjadi salah satu mata pelajaran wajib yang harus ada dalam setiap pembelajaran disekolah maupun di perguruan tinggi. Mata Kuliah Aljabar Linier merupakan salah satu mata kuliah dalam bidang study matematika yang di ajarkan pada mahasiswa jurusan sistem informasi fakultas ilmu komputer Universitas Putra Indonesia "YPTK" Padang. Mata kuliah aljabar linier ini di berikan pada semester III atau merupakan semester ganjil dengan beban 3 sks. Setelah mempelajari aljabar linier ini diharapkan mahasiswa mempunyai kompetensi atau kemampuan dalam menyelesaikan masalah-masalah yang berkaitan dengan aljabar linier dan mahasiswa mampu mengaplikasikannya dalam bidang ilmu lainnya, seperti bidang bisnis, ekonomi, teknik, fisika baik ilmu lainnya.

Kemampuan memecahkan masalah yang diperoleh siswa dalam matematika merupakan kemampuan yang akan digunakan dalam memecahkan masalah-masalah keseharian siswa dan merupakan sarana mempelajari ide matematika dan membentuk kemampuan matematis lainnya. Dalam pendidikan matematika, salah satu kemampuan matematis yang harus dimiliki oleh mahasiswa dan sangat penting yaitu kemampuan komunikasi. (NCTM, 1989) menyatakan bahwa kemampuan komunikasi dalam pembelajaran matematika dapat dilihat dari (1) kemampuan mengekspresikan ide-ide matematika melalui lisan, tertulis, dan mendemontrasikannya serta menggambarkannya secara visual (2) kemampuan memahami, menginterpretasikan dan mengevaluasi ide-ide matematika baik secara lisan, tulisan, maupun dalam bentuk visual lainnya (3) kemampuan dalam menggunakan istilah-istilah, notasi-notasi matematika dan strukturstrukturnya, untuk menyajikan ide-ide, menggambarkan hubungan-hubungan dan model-model situasi. Sedangkan menurut Umar dalam (Sonarita, Bharata, \& Asnawati, 2014), kemampuan komunikasi matematis siswa adalah bagaimana siswa mengomunikasikan ide-idenya dalam usaha memecahkan masalah yang diberikan guru, berpartisipasi aktif dalam diskusi, dan mempertanggungjawabkan jawaban mereka terhadap masalah.

Melalui komunikasi, siswa dapat mengeksplorasi pemikiran matematisnya, mengembangkan pola pikir, dan menghubungkan gagasan satu dengan gagasan yang lain, sehingga dapat meningkatkan pemahaman konsep - konsep abstrak dalam pembelajaran matematika yang dihadapi oleh siswa sehingga keadaan atau masalah yang dihadapi terlihat lebih jelas (Rahmawati, Usodo, \& Chrisnawati, 2017). Dalam penelitian ini, indikator yang digunakan dalam menentukan

tingkat kemampuan komunikasi matematika pada mata kuliah aljabar linier adalah mahasiswa mampu membuat sajian visual atau gambar untuk memperjelas permasalahan dan memfasilitasi penyelesaiannya.

Beberapa penelitian terdahulu juga telah mengalisis tentang kemampuan komunikasi seperti yang dilakukan oleh (Romadhon, 2016) yang menganalisis kemampuan komunikasi 


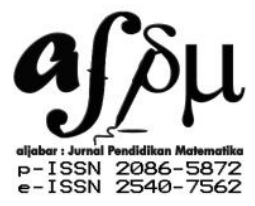

Al-Jabar: Jurnal Pendidikan Matematika

Vol. 8, No. 1, 2017, Hal 53 - 62

matematis siswa SMP pada materi kubus dan balok, (Rahmawati et al., 2017) menganalisis kemampuan komunikasi matematis secara tertulis ditinjau dari perbedaan gender, (Lamonta, Tandiayuk, \& Puluhulawa, 2016) menganalisis kemampuan komunikasi matematis dalam memahami volume balok.

Kemampuan matematis yang juga penting selain kemampuan komunikasi adalah pemahaman konsep. Pemahaman konsep adalah penguasaan sejumlah materi pembelajaran, dimana siswa tidak hanya mengenal dan mengetahui, tapi mampu mengungkapkan kembali dalam bahasa yang mudah dimengerti serta mampu mengaplikasikannya (Fadzillah \& Wibowo, 2016). Untuk menunjukkan kemampuan pemahaman konsep dapat digunakan beberapa indikator misalnya menyatakan ulang sebuah konsep, mengklarifikasikan objek menurut sifat-sifat tertentu (sesuai dengan konsepnya), memberi contoh bukan contoh dari konsep, meyajikan konsep dalam berbagai bentuk representasi matematis, mengembangkan syarat perlu dan syarat cukup suatu konsep, menggunakan, memanfaatkan dan memilih prosedur tertentu (Depdiknas, 2004).

Dalam pelajaran matematika masih ditemukan adanya siswa yang mengalami kesulitan dalam pemahaman konsep. Banyak siswa yang hanya menghafalkan konsep dan tidak memahami penyelesaian dengan benar. Karenanya hasil yang dicapai tidak memuaskan dan tidak maksimal (Fadzillah \& Wibowo, 2016). Hal ini sesuai dengan penelitian relevan yaitu oleh (Yolanda, Syuhendri, \& Andriani, 2016) dalam hasil penelitiannya yang menyatakan bahwa pemahaman konsep siswa materi suhu dan kalor dinilai masih rendah dan terdapat miskonsepsi pada seluruh konsep yang diujikan dan menurut (Fadzillah \& Wibowo, 2016) dalam penelitiannya menghasilkan bahwa beberapa kesulitan yang dialami siswa yaitu pada saat menentukan model matematika sehingga siswa belum mampu untuk menyajikan konsep secara representasi matematis, mengaplikasikan konsep dengan menggunakan algoritma yang tepat, dan belum mampu mengaitkan antar konsep yang terdapat pada soal.

Dalam penelitian ini, indikator yang digunakan dalam menentukan tingkat pemahaman konsep pada mata kuliah aljabar linier adalah mahasiswa mampu menerapkan konsep dengan benar dalam menyelesaikan persoalan-persoalan yang diberikan.

Berdasarkan hal tersebut, keterbaruan penulis yaitu untuk menggambarkan dua kemampuan matematis yaitu kemampuan komunikasi dan pemahaman konsep pada mata kuliah aljabar linear. Tujuan dari penelitian ini adalah mendeskripsikan kemampuan komunikasi dan pemahaman konsep mahasiswa menyelesaikan soal aljabar linier pada pokok bahasan vektor berdasarkan indikator kemampuan komunikasi dan pemahaman konsep serta level kemampuan mahasiswa.

\section{METODE PENELITIAN}


Penelitian ini merupakan penelitian deskriptif yang bertujuan mendeskripsikan kemampuan komunikasi dan pemahaman konsep mahasiswa pada mata kuliah aljabar linier. Penelitian ini dilakukan di jurusan sistem informasi fakultas ilmu computer universitas putra Indonesia YPTK Padang semester ganjil tahun akademik 2016/2017. Subjek dari penelitian ini adalah mahasiswa yang mengampu mata kuliah aljabar linier pada kelas SI 10 sebanyak 48 orang.

Instrument yang digunakan adalah instrument tes uraian. Tes uraian uraian tersebut terdiri dari 2 soal kemampuan komunikasi dan 5 soal pemahaman konsep. Soal kemampuan komunikasi meminta mahasiswa menggunakan atau membuat sajian visual atau gambar untuk memperjelas permasalahan dan memfasilitasi penyelesaiannya. Dan soal pemahaman konsep meminta mahasiswa menjelaskan konsep dengan benar dan menggunakan konsep dengan benar dalam menjawab soal pemahaman konsep. Hasil dari tes tersebut akan dideskripsikan secara kuantitatif dan beberapa jawaban mahasiswa akan dideskrifsikan secara kualitatif. Dalam penelitian ini, dipilih 2 subjek yang dideskripsikan jawabannya yaitu subjek 1 dengan mahasiswa berkemampuan tinggi dan subjek 2 dengan berkemampuan rendah. Masing-masing soal akan dideskripsikan sesuai dengan jawaban mahasiswa berkemampuan tinggi dan mahasiswa berkemampuan rendah untuk melihat kemampuan komunikasi dan pemahaman konsep mahasiswa.

\section{HASIL PENELITIAN DAN PEMBAHASAN}

Data kuantitatif yang diperoleh dalam penelitian ini adalah data skor akhir kemampuan komunikasi dan pemahaman konsep mahasiswa hal ini berkaitan dengan kemampuan komunikasi meminta mahasiswa menggunakan atau membuat sajian visual atau gambar untuk memperjelas permasalahan dan memfasilitasi penyelesaiannya dan pemahaman konsep meminta mahasiswa menjelaskan konsep dengan benar dan menggunakan konsep dengan benar dalam menyelesaikan soal. Pengambilan data penelitian dilakukan pada tanggal 6 januari 2017 kampus UPI YPTK Padang pada jam 13.30 sampai 15.30 WIB dimana pada waktu ini subjek penelitian mengerjakan lembar instrument kemampuan komunikasi dan pemahaman konsep. Dari hasil tes inilah peneliti melakukan analisis data untuk memperoleh gambaran tentang kemampuan komunikasi dan pemahaman konsep pada pokok bahasan vektor mahasiswa UPI YPTK Padang

Table 1. berikut adalah paparan kemampuan komunikasi dan pemahaman konsep mahasiswa SI10 UPI YPTK Padang pada pokok bahasan vektor di tinjau dari indikator-indikator kemampuan komunikasi dan pemahaman konsep dan level kemampuan mahasiswa.

Tabel 1. Kemampuan komunikasi dan pemahaman konsep mahasiswa. 


\begin{tabular}{|c|c|c|c|c|c|c|c|c|c|c|c|c|c|c|}
\hline \multirow{4}{*}{$\begin{array}{c}\text { Level } \\
\text { kemampuan } \\
\text { mahasiswa }\end{array}$} & \multicolumn{14}{|c|}{ Kemampuan } \\
\hline & \multicolumn{4}{|c|}{ Komunikasi } & \multicolumn{10}{|c|}{ Pemahaman Konsep } \\
\hline & \multicolumn{2}{|c|}{$1 \mathrm{a}$} & \multicolumn{2}{|c|}{6} & \multicolumn{2}{|c|}{$1 \mathrm{~b}$} & \multicolumn{2}{|c|}{2} & \multicolumn{2}{|c|}{3} & \multicolumn{2}{|c|}{4} & \multicolumn{2}{|c|}{5} \\
\hline & B & $\mathrm{S}$ & B & $\mathrm{S}$ & B & $\mathrm{S}$ & B & $\mathrm{S}$ & B & $\mathrm{S}$ & B & $\mathrm{S}$ & B & $\mathrm{S}$ \\
\hline \multirow[t]{2}{*}{ Keseluruhan } & 39 & 9 & 22 & 26 & 38 & 10 & 35 & 13 & 33 & 15 & 30 & 18 & 21 & 27 \\
\hline & 81,3 & 18,8 & 45,8 & 54,2 & 79,2 & 20,8 & 72,9 & 27,1 & 68,8 & 31,3 & 62,5 & 37,5 & 43,8 & 56,3 \\
\hline Rata-rata B & \multicolumn{4}{|c|}{$63,58 \%$} & \multicolumn{10}{|c|}{$65,44 \%$} \\
\hline \multirow[t]{2}{*}{ Tinggi } & 13 & 3 & 12 & 4 & 12 & 4 & 15 & 1 & 15 & 1 & 13 & 3 & 10 & 6 \\
\hline & 81,3 & 18,8 & 75,0 & 25,0 & 75,0 & 25,0 & 93,8 & 6,3 & 93,8 & 6,3 & 81,3 & 18,8 & 62,5 & 37,5 \\
\hline Rata-rata B & \multicolumn{4}{|c|}{$50,05 \%$} & \multicolumn{10}{|c|}{$81,34 \%$} \\
\hline \multirow[t]{2}{*}{ Rendah } & 12 & 4 & 5 & 11 & 14 & 2 & 10 & 6 & 10 & 6 & 8 & 8 & 5 & 11 \\
\hline & 75,0 & 25,0 & 31,3 & 68,8 & 87,5 & 12,5 & 62,5 & 37,5 & 62,5 & 37,5 & 50,0 & 50,0 & 31,3 & 68,8 \\
\hline Rata-rata B & \multicolumn{4}{|c|}{$50 \%$} & \multicolumn{10}{|c|}{$46,26 \%$} \\
\hline
\end{tabular}

Indikator-indikator kemampuan Komunikasi dan pemahaman Konsep

1. Kemampuan Komunikasi : Membuat sajian visual atau gambar untuk memperjelas permasalahan dan memfasilitasi penyelesaiannya.

2. Pemahaman Konsep : Menerapkan Konsep dengan benar, menjelaskan konsep dengan benar.

\section{Pembahasan}

a. Analisa data mahasiswa secara keseluruhan

Berdasarkan Tabel.1 dapat dilihat bahwa secara keseluruhan kemampuan komunikasi matematika mahasiswa pada soal no 1a mahasiswa menjawab dengan benar sebanyak 39 orang (81,3\%) sedangkan untuk soal kemampuan komunikasi yang kedua yaitu item soal no 6 secara keseluruhan mahasiswa sebanyak 22 orang $(45,8 \%)$ menjawab dengan benar. Dan secara rata-rata ada $63,8 \%$ mahasiswa menjawab soal kemampuan komunikasi matematika dengan benar. Untuk kemampuan komunikasi mahasiswa secara keseluruhan dapat disimpulkan bahwa mahasiswa sebagian sudah mampu membuat sajian visual atau gambar untuk memperjelas permasalahan dan memfasilitasi penyelesaiannya. Selanjutnya hanya sebagian mahasiswa yang belum mampu menggunakan atau membuat sajian visual atau gambar untuk memperjelas permasalahan dan memfasilitasi penyelesaiannya.

Untuk pemahaman konsep mahasiswa secara keseluruhann ada terdapat 5 item soal pemahaman konsep dengan indicator mahasiswa mampu menjelaskan konsep dengan benar dan mampu menggunakan konsep dengan benar, item soal tersebut adalah soal no 1b, 2, 3, 4, dan item soal no 5. Secara keseluruhan mahasiswa yang menjawab item-item pemahaman konsep dengan benar berdasarkan item soalnya adalah 38 orang $(79,2 \%)$ untuk item soal no $1 \mathrm{~b}, 10$ orang $(62,5 \%)$ 


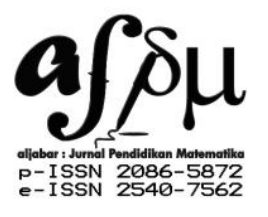

Al-Jabar: Jurnal Pendidikan Matematika

Vol. 8, No. 1, 2017, Hal 53 - 62

item soal no 2 dan item soal no3, 30 orang $(62,5 \%)$ item soal no 4, 21 orang $(43,8 \%)$ item soal no 5. Dari data ini dapat disimpulkan bahwa secara rata-rata $65,44 \%$ mahasiswa secara keseluruhan sudah mampu menjelaskan konsep dengan benar dan menggunakan konsep dengan benar.

b. Analisa mahasiswa berkemampuan tinggi

Mahasiswa berkemampuan tinggi berjumlah 16 orang. Dari Tabel.1 untuk soal kemampuan komunikasi ada 2 item soal yaitu item soal no 1 a dan item soal no 6 . Dari kedua item soal tersebut terdapat 13 orang $(81,3 \%)$ yang menjawab dengan benar item soal no 1a dan terdapat 12 orang (75\%) yang menjawab dengan benar item soal no 6. Dari item-item soal kemampuan komunikasi ini dapat dilihat bahwa secara rata-rata 50,05\% mahasiswa kemampuan tinggi sudah mampu membuat sajian visual atau gambar untuk memperjelas permasalahan dan memfasilitasi penyelesaiannya.

Untuk pemahaman konsep mahasiswa berkemampuan tinggi ada terdapat 5 item soal pemahaman konsep dengan indicator mahasiswa mampu menjelaskan konsep dengan benar dan mampu menggunakan konsep dengan benar, item soal tersebut adalah soal no $1 \mathrm{~b}, 2,3$, 4, dan item soal no 5. Mahasiswa berkemampuan tinggi yang menjawab item-item pemahaman konsep dengan benar berdasarkan item soalnya adalah 12 orang $(75,0 \%)$ untuk item soal no $1 \mathrm{~b}, 15$ orang $(93,8 \%)$ item soal no 2 dan item soal no3, 13 orang $(81,3 \%)$ item soal no 4,10 orang $(62,5 \%)$ item soal no 5. Dari data ini dapat disimpulkan bahwa secara rata-rata $81,34 \%$ mahasiswa berkemampuan tinggi mampu menjelaskan konsep dengan benar dan menggunakan konsep dengan benar.

Untuk data kualitatif, diambil 2 subjek yaitu subjek dengan kemampuan baik dan subjek dengan kemampuan rendah untuk dipaparkan jawaban dari setiap soal yang diberikan. Berikut deskripsi kualitatif dari mahasiswa berkemampuan tinggi :

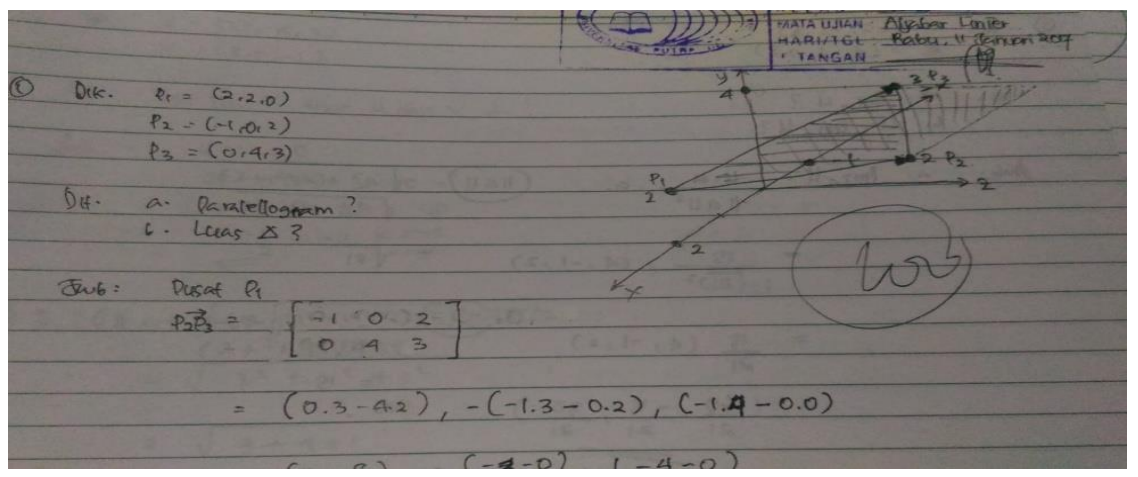

Gambar1. Jawaban kemampuan komunikasi mahasiswa berkemampuan tinggi

Gambar.1 adalah soal no 1a dimana pada soal ini memuat indicator kemampuan komunikasi matematika mahasiswa yaitu mahasiswa diminta mampu membuat sajian visual atau gambar untuk memperjelas permasalahan dan memfasilitasi penyelesaiannya. 65,44\% mahasiswa berkemampuan tinggi sudah mampu membuat sajian visual atau gambar untuk memperjelas permasalahan dan memfasilitasi penyelesaiannya dan sisanya $34,56 \%$ saja mahasiswa 


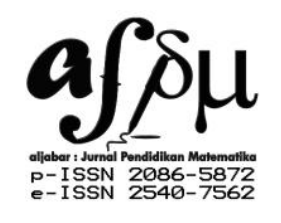

berkemampuan tinggi yang tidak mampu membuat sajian visual atau gambar untuk memperjelas permasalahan dan memfasilitasi penyelesaiannya. Jawaban di atas merupakan jawaban mahasiswa berkemampuan tinggi yang sudah mampu membuat sajian visual atau gambar untuk memperjelas permasalahan dan memfasilitasi penyelesaiannya mampu menjelaskan konsep dengan benar dan menggunakan konsep dengan benar.

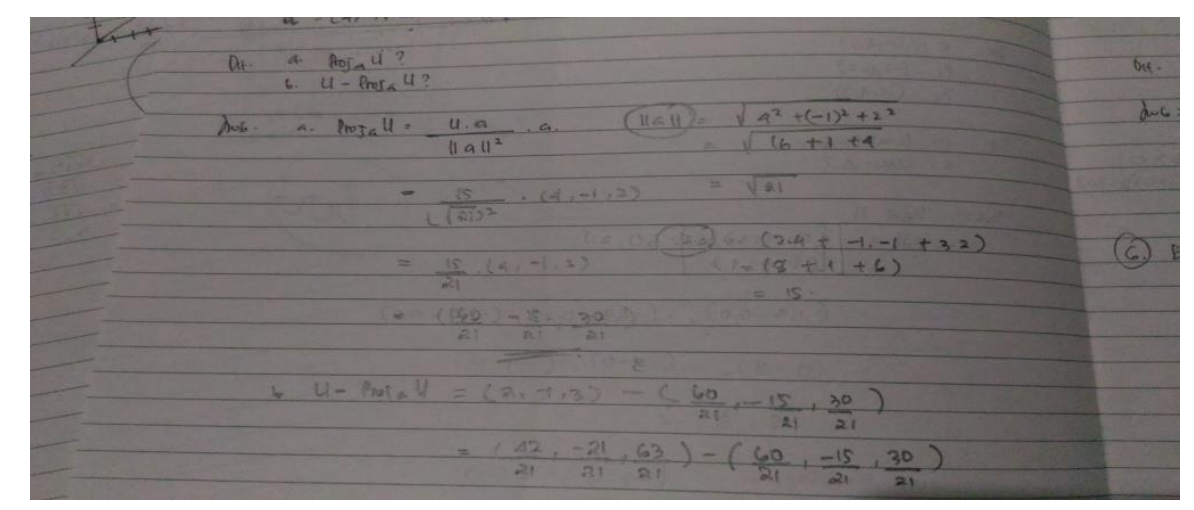

Gambar 2. Jawaban pemahaman konsep mahasiswa berkemampuan tinggi

Gamabar 2. adalah soal no 5 dimana pada soal ini memuat indicator pemahaman konsep yaitu mahasiswa diminta menjelaskan konsep dengan benar dan menggunakan konsep dengan benar. 81,34\% mahasiswa berkemampuan tinggi sudah mampu menjelaskan konsep dengan benar dan menggunakan konsep dengan benar dan sisanya $18,66 \%$ saja mahasiswa berkemampuan tinggi yang tidak mampu menjelaskan konsep dengan benar dan menggunakan konsep dengan benar. Jawaban di atas merupakan jawaban mahasiswa berkemampuan tinggi yang sudah mampu menjelaskan konsep dengan benar dan menggunakan konsep dengan benar.

c. Analisa mahasiswa berkemampuan rendah

Mahasiswa berkemampuan rendah berjumlah 16 orang. Dari Tabel.1 untuk soal kemampuan komunikasi ada 2 item soal yaitu item soal no 1 a dan item soal no 6 . Dari kedua item soal tersebut terdapat 12 orang $(75,0 \%)$ yang menjawab dengan benar item soal no 1a dan terdapat 5 orang $(31,3 \%)$ yang menjawab dengan benar item soal no 6. Dari item-item soal kemampuan komunikasi ini dapat dilihat bahwa secara rata-rata 50\% mahasiswa kemampuan rendah mampu membuat sajian visual atau gambar untuk memperjelas permasalahan dan memfasilitasi penyelesaiannya.

Untuk pemahaman konsep mahasiswa berkemampuan tinggi ada terdapat 5 item soal pemahaman konsep dengan indicator mahasiswa mampu menjelaskan konsep dengan benar dan mampu menggunakan konsep dengan benar, item soal tersebut adalah soal no 1b, 2, 3, 4, dan item soal no 5. Mahasiswa berkemampuan rendah yang menjawab item-item pemahaman konsep dengan benar berdasarkan item soalnya adalah 14 orang $(87,5 \%)$ untuk item soal no $1 \mathrm{~b}, 10$ orang $(62,75 \%)$ item soal no 2 dan item soal no3, 8 orang $(50,0 \%)$ item soal no 4,5 orang $(31,3 \%)$ item soal no 5 . Dari 


\section{$\mathbf{a} \int \rho \mu$}

Al-Jabar: Jurnal Pendidikan Matematika

Vol. 8, No. 1, 2017, Hal 53 - 62

data ini dapat disimpulkan bahwa secara rata-rata 46,26\% mahasiswa berkemampuan rendah belum mampu menjelaskan konsep dengan benar dan menggunakan konsep dengan benar.

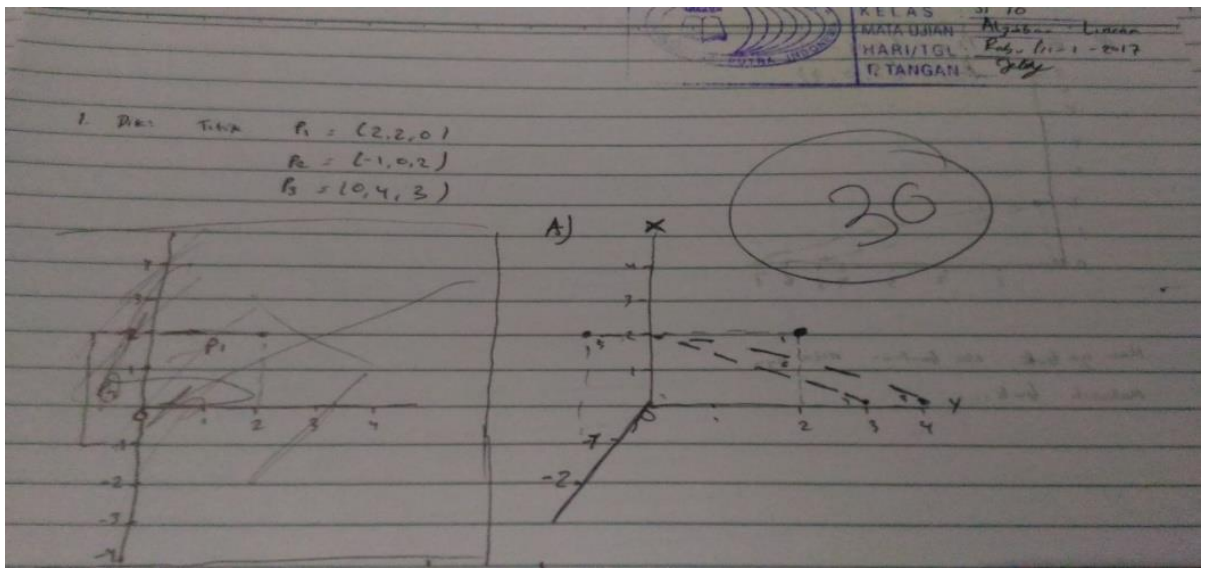

Gambar 3. Jawaban kemampuan komunikasi mahasiswa berkemampuan rendah

Gambar 3. adalah soal no 1a dimana pada soal ini memuat indicator kemampuan komunikasi matematika mahasiswa yaitu mahasiswa diminta mampu membuat sajian visual atau gambar untuk memperjelas permasalahan dan memfasilitasi penyelesaiannya. Dari $50 \%$ mahasiswa berkemampuan rendah yang sudah mampu membuat sajian visual atau gambar untuk memperjelas permasalahan dan memfasilitasi penyelesaiannya.dan sisa nya 50\% mahasiswa berkemampuan rendah yang belum mampu mampu membuat sajian visual atau gambar untuk memperjelas permasalahan dan memfasilitasi penyelesaiannya, tampak dari jawaban mahasiswa berkemampuan rendah diatas adalah salah satu jawaban yang menggambarkan bahwa mahasiswa kemampuan rendah belum mampu membuat sajian visual atau gambar untuk memperjelas permasalahan dan memfasilitasi penyelesaiannya.

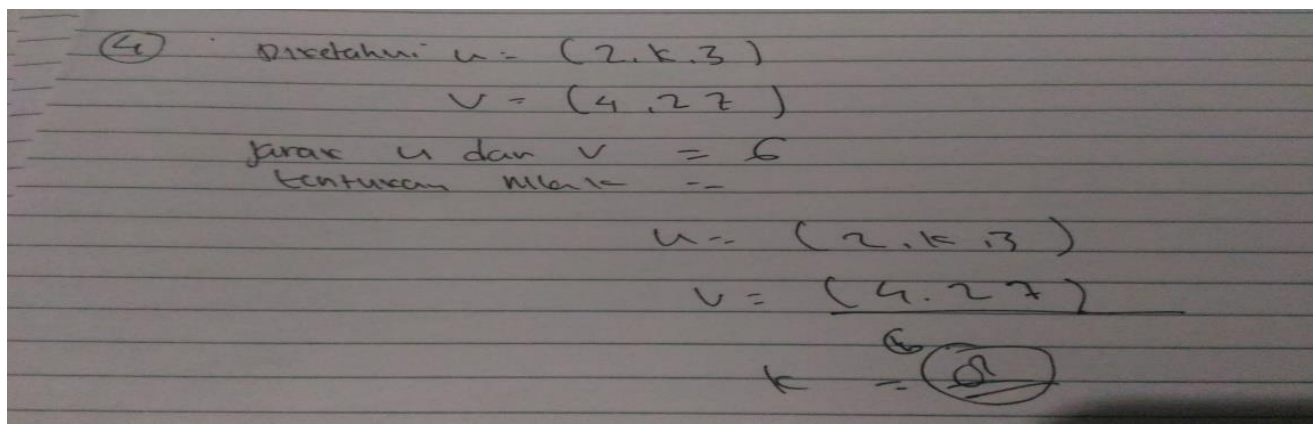

Gambar 4. Jawaban pemahaman konsep mahasiswa berkemampuan rendah

Gambar 4. adalah soal no 4 dimana pada soal ini memuat indicator pemahaman konsep yaitu mahasiswa diminta menjelaskan konsep dengan benar dan menggunakan konsep dengan benar. Dari 46,26\% mahasiswa berkemampuan rendah yang sudah mampu menjelaskan konsep dengan benar dan menggunakan konsep dengan benar dan sisa nya 53,74\% mahasiswa 


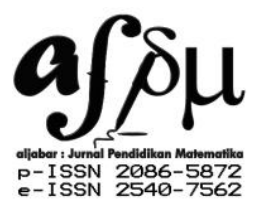

Al-Jabar: Jurnal Pendidikan Matematika

Vol. 8, No. 1, 2017, Hal 53 - 62

berkemampuan rendah yang belum mampu menjelaskan konsep dengan benar dan menggunakan konsep dengan benar, tampak dari jawaban mahasiswa berkemampuan rendah diatas adalah salah satu jawaban yang menggambarkan bahwa mahasiswa kemampuan rendah belum mampu menjelaskan konsep dengan benar dan menggunakan konsep dengan benar.

Berdasarkan hasil analisis diatas, terdapat kesamaan hasil pada penelitian terdahulu oleh (Arifin et al., 2016) yang menyatakan bahwa siswa dengan kemampuan matematika tinggi memiliki kemampuan komunikasi yang sangat baik dan memenuhi semua indikator, siswa berkemampuan matematika sedang memiliki kemampuan komunikasi yang baik dengan memenuhi 3 indikator, dan siswa dengan kemampuan matematika rendah memiliki kemampuan komunikasi cukup yang hanya mampu memenuhi 1 indikator dan masih terdapat kesalahan dan (Widiawati, Pudjawan, \& I Gede Margunayasa, 2015) dengan hasil penelitian yang menunjukkan bahwa $10,81 \%$ peserta didik memperoleh nilai rata- rata dari tes pemahaman konsep IPA, sebanyak $45,95 \%$ peserta didik memperoleh nilai dibawah rata-rata dan sebanyak $43,24 \%$ peserta didik memperoleh nilai diatas rata-rata. Sedangkan hasil analisis indikator menunjukkan bahwa memberi contoh merupakan indikator dengan persentase tertinggi yaitu dengan jumlah persentase $88,92 \%$ dan indikator menjelaskan merupakan indikator dengan persentase terendah dengan perolehan persentase sebesar $60,81 \%$.

\section{SIMPULAN DAN SARAN}

Dari hasil penelitian ini dapat disimpulkan bahwa untuk kemampuan komunikasi 63,58\% mahasiswa secara keseluruhan, 50,05\% mahasiswa yang berkemampuan tinggi, dan 50\% mahasiswa berkemampuan rendah mampu membuat sajian visual atau gambar untuk memperjelas permasalahan dan memfasilitasi penyelesaiannya. Untuk pemahaman konsep mahasiswa secara keseluruhan $65,44 \%$, mahasiswa yang berkemampuan tinggi $81,34 \%$, mahasiswa berkemampuan rendah 46,29\% mempunyai pemahaman konsep mampu menjelaskan konsep dengan benar dan menggunakan konsep dengan benar.

Saran-saran yang dapat penulis berikan untuk peneliti selanjutnya adalah bahwa penelitian ini hanya mendeskripsikan bagaimana kemampuan komunikasi dan pemahaman konsep mahasiswa dengan memberikan soal-soal kemampuan komunikasi dan pemahaman konsep saja, agar penelitian selanjutnya peneliti dapat menggunakan tes dan wawancara mahasiswa sebagai instrument penelitian dan agar para peneliti lainnya ataupun pendidik dan dosen agar memperhatikan kemampuan komunikasi dan pemahaman konsep peserta didik.

\section{DAFTAR PUSTAKA}

Arifin, Z., Trapsilasiwi, D., \& Fathillah, A. (2016). Analisis Kemampuan Komunikasi Matematika Dalam Menyelesaikan Masalah Pada Pokok Bahasan Sistem Persamaan Linier Dua Variabel Siswa Kelas VIII-C SMP Nuris Jember. Jurnal Edukasi Unej, 3(2), 9-12. 
Depdiknas. (2004). Pedoman Umum Pengembangan Bahan Ajar. Jakarta: Direktorat Pendidikan Menengah Umum.

Fadzillah, N., \& Wibowo, T. (2016). Analisis Kesulitan Pemahaman Konsep Matematika Kelas VII SMP. Ekuivalen, 20(2), 140-144.

Lamonta, P. A., Tandiayuk, M. B., \& Puluhulawa, I. (2016). Analisis Kemampuan Komunikasi Matematis Siswa Kelas VIII SMP Negeri 19 Palu Dalam Memahami Volume Balok. Jurnal Elektronik Pendidikan Matematika Tadulako, 3(4), 464-477.

NCTM. (1989). Curriculum Evaluation Standard for School Mathematics. Virginia: The NCTM Inc.

Rahmawati, R. P. D., Usodo, B., \& Chrisnawati, H. E. (2017). Analisis Kemampuan Komunikasi Matematis Secara Tertulis Peserta Didik Kelas X SMA N 1 Sukoharjo Ditinjau Dari Perbedaan Gender. JPPM, 1(3), 61-70.

Romadhon, S. (2016). Analisis Kemampuan Komunikasi Matematis Siswa SMP Pada Materi Kubus Dan Balok. Ekuivalen, 20(3), 167-172.

Santrock, J. W. (2008). Psikologi Pendidikan. Jakarta: Kencana.

Sonarita, G., Bharata, H., \& Asnawati, R. (2014). Peningkatan Kemampuan Komunikasi Matematis Melalui Model Pembelajaran Kooperatif Tipe Three-Step Interview. Jurnal Pendidikan Matematika Unila, 2(4).

Widiawati, N. P., Pudjawan, K., \& I Gede Margunayasa. (2015). Analisis Pemahaman Konsep Dalam Pembelajaran IPA Pada Siswa Kelas IV SD Di Gugus II Kecamatan Banjar. MIMBAR PGSD Undiksha, 3(1).

Yolanda, R., Syuhendri, \& Andriani, N. (2016). Analisis Pemahaman Konsep Siswa SMA Negeri Se- Kecamatan Ilir Barat I Palembang Pada Materi Suhu Dan Kalor Dengan Instrumen TTCI Dan CRI. Jurnal Inovasi Dan Pembelajaran Fisika, 3(1), 1-13. 